\title{
Tropical forages: morphoanatomy of plants grown in areas with the death of pasture syndrome
}

\author{
N. G. Ribeiro-Júniora, ${ }^{a, b *}$, O. S. Fagundes ${ }^{b}$, A. S. Benevenutic, O. M. Yamashita ${ }^{a}$, \\ A. A. B. Rossi ${ }^{a}$, M. A. C. Carvalho and I. V. Silva ${ }^{a, b}$ \\ aPrograma de Pós-graduação em Biodiversidade e Agroecossistemas Amazônicos, \\ Universidade do Estado de Mato Grosso - UNEMAT, Avenida Perimetral Rogério Silva, 4930, \\ Bairro Flamboyant, CEP 78580-000, Alta Floresta, MT, Brazil \\ bLaboratório de Biologia Vegetal, Faculdade de Ciências Biológicas e Agrárias, \\ Universidade do Estado de Mato Grosso - UNEMAT, Avenida Perimetral Rogério Silva, 4930, \\ Bairro Flamboyant, CEP 78580-000, Alta Floresta, MT, Brazil \\ 'Programa de Pós-graduação em Genética e Melhoramento de Plantas, \\ Universidade do Estado de Mato Grosso - UNEMAT, Avenida Perimetral Rogério Silva, 4930, \\ Bairro Flamboyant, CEP 78580-000, Alta Floresta, MT, Brazil \\ *e-mail: biologo_norbertojunior@hotmail.com
}

Received: July 2, 2016 - Accepted: July 6, 2016 - Distributed: November 31, 2017

(With 3 figures)

\begin{abstract}
Roots and leaves of Panicum maximum Tanzânia, Mombaça and Massai; Urochloa brizantha Piatã, Marandu and Xaraés; Urochloa humidicola Llanero; Urochloa ruziziensis Ruzizienses; Urochloa hybrida Mulato II and Cynodon nlemfuensis Estrela-roxa were analyzed, seeking to identify characters for better adaptation to the environment that may interfere with digestibility of tissue from the point of view of the rumen in cattle. Were planted ten cultivars in a completely randomized blocks with three repetitions. Was collected vegetative material, which histological slides were prepared from middle third of the sections of roots and leaves. Were observed differences $(p>0.05)$ in the roots: higher volume of epidermal cells $(28.62 \mu \mathrm{m})$ and overall diameter $(1926.41 \mu \mathrm{m})$ of Llanero; thicker vascular cylinder $(975.09 \mu \mathrm{m})$ and more protoxylem (42.25) in Estrela-roxa and occurrence of aerenchyma in cultivars Piatã, Mulato II, Xaraés, Massai, Llanero and Estrela-roxa; Were found higher proportions of bulliform cells in the leaves $(121.07 \mu \mathrm{m})$ and thicker leaf mesophyll in $U$. humidicola Llanero $(263.63 \mu \mathrm{m})$; higher proportion of sclerenchyma fibers in Xaraés and Marandu; lower results for amount of fibers in P. maximum Massai. We conclude that the cultivars Estrela-roxa, Llanero and Massai have greater adaptability to the environment and better nutritional quality.
\end{abstract}

Keywords: Urochloa, Cynodon, digestibility, Panicum.

\section{Forrageiras tropicais: anatomia e morfometria de plantas cultivadas em áreas com síndrome da morte de pastagens}

\section{Resumo}

Foram analisadas raízes e folhas de Panicum maximum Tanzânia, Mombaça e Massai; Urochloa brizantha Piatã, Marandu e Xaraés; Urochloa humidicola Llanero; Urochloa ruziziensis Ruzizienses; Urochloa hybrida Mulato II e Cynodon nlemfuensis Estrela-roxa, procurando identificar caracteres relacionados à melhor adaptação ao ambiente $\mathrm{e}$ à qualidade nutritiva das forrageiras. As dez cultivares foram semeadas em blocos inteiramente casualizados com três repetições. Após estabelecidas foi coletado material vegetativo, do qual lâminas histológicas foram confeccionadas a partir de secções do terço médio de raízes e folhas. Foram observadas diferenças significativas $(p>0,05)$ nas raízes: maior volume de células epidérmicas $(28,62 \mu \mathrm{m})$ e diâmetro total $(1926,41 \mu \mathrm{m})$ de Llanero; em Estrela-roxa maior espessura do cilindro vascular $(975,09 \mu \mathrm{m})$ e número maior de protoxilemas $(42,25)$ e formação de aerênquimas nas cultivares Piatã, Mulato II, Xaraés, Massai, Llanero, e Estrela-roxa; Nas folhas, foram constatadas maiores proporções de células buliformes $(121,07 \mu \mathrm{m})$ e mesofilo foliar mais espesso $(263,63 \mu \mathrm{m})$ em Llanero; em Xaraés e Marandu maiores proporções de fibras esclerenquimáticas; em Massai menores resultados para quantidade de fibras. Conclui-se que as cultivares Estrela-roxa, Llanero e Massai apresentam maior adaptabilidade ao ambiente e melhor qualidade nutritiva.

Palavras-chave: Urochloa, Cynodon, digestibilidade, Panicum. 


\section{Introduction}

The grasses are constituted by an intricate arrangement of roots, stem, leaves and inflorescences, and each structure has its genesis of tissues properly organized for particular functions (Valente et al., 2011). The tissues differ chemically and physically, depending on their role of assimilation, transportation, support or reserve accumulation (Queiroz et al., 2000).

The leaf anatomy influences not only the production of forage but also its nutritional value and the animal performance (Paciullo et al., 2002). The digestion of thin-walled cells like the foliar mesophyll and the phloem is faster than the cells of the xylem and the bundles of sclerenchyma fibers.

The anatomy of the organs of the plant and its constituent tissues have an influence on the consumption because of the effect they produce on the ease of fragmentation of the particles of the forages, the nature of the particles produced and their rate of passage through the rumen (Carvalho and Pires, 2008). The anatomical knowledge of the forage grasses may contribute to their best use in the ruminant feed (Brito and Deschamps, 2001).

The several studies reported in the literature and methodologies for the development of new cultivars evaluate the production of green and dry mass in the flowerbeds, digestibility of the aerial parts of the forage, resistance to soil waterlogging and pests, which requires time and a multidisciplinary team. By normally cover a large number of genotypes, the improvement programs mainly use the agronomic characteristics of the forage, to the detriment of the anatomical and morphophysiological, in the selection of genotypes (Gomes et al., 2011). This generates little knowledge about the internal structural characteristics of the cultivars.

The low nutritional value of tropical forages is reported in the literature (Gerdes et al., 2000), based mainly by the higher proportion of fibers in relation to the low content of crude protein and minerals, when the comparison is made to natural grass from temperate areas. Knowing the anatomy along with the chemical composition and the digestibility may improve the comprehension about the factors that limit the utilization of the forage by ruminants (Queiroz et al., 2000).

In this paper we attempted to describe anatomically and morphometrically the roots and the leaf blades of ten cultivars of forage grasses sown in area of sudden death pasture (DPS), noting characters that may be related to a better adaptation of the plant to the environment and / or that may interfere in the digestibility of the tissues, from the point of view of the ruminal degradation in cattle.

\section{Materials and Methods}

\subsection{Study area}

The forages Panicum maximum Jacq, cultivars: Tanzânia, Mombaça e Massai; Urochloa brizantha Hochst Stapf, cultivars: BRS Piatã, Marandu and Xaraés;
Urochloa humidicola (Rendle) Schweick cv. Llanero; Urochloa ruziziensis Germain et Evrard cv. Ruzizienses; Urochloa hybrida cv. Mulato II and Cynodon nlemfuensis Vanderyst (Estrela-roxa or Estrela-roxa-africana) were cultivated in the Experimental area of the University of the State of Mato Grosso in partnership with EMBRAPA Beef Cattle - Sinop, in 2014.

The site is located in the extreme north of Mato Grosso, southern Amazon, in latitude of 9 51'03's, longitude of $56^{\circ} 12^{\prime} 35^{\prime \prime} \mathrm{E}$ and altitude of $255 \mathrm{~m}$. The region is part of the South American Amazon depression, with a humid continental equatorial climate and presents two well-defined seasons: dry winter, from May to July, and rainy summer. The annual rainfall can exceed $2,300 \mathrm{~mm} \mathrm{~m}^{-2}$ and the average temperature is $24.8^{\circ} \mathrm{C}$ (SEPLAN, 2006).

\subsection{Experimental delineation}

The experimental delineation used for planting was the randomized blocks, with three repetitions for each cultivar. The plants were planted in blocks an area previously used with an extensive system of pasture with $U$. brizantha $\mathrm{cv}$. Marandu for 12 years. The grass in this area had focus of death by the death of pastures syndrome (DPS). The area of the experiment, as well as 5 meters of its surroundings, was desiccated with the use of the glyphosate herbicide, followed by the disking for the soil decompression and subsequent liming for the correction of the soil chemical properties. Thirty fractions were assembled, measuring $5.0 \mathrm{~m}$ long and $6.0 \mathrm{~m}$ wide each, with the distance of $1.0 \mathrm{~m}$ between them. Once the area was prepared, the portions were numbered and randomly selected one at a time for seeding of the 10 forages. From the established plants, about 40 days after seeding, the pruning cycles at $10 \mathrm{~cm}$ above the soil were initiated, and they were repeated every 28 days. After four cutting cycles (pruning), in April 2014, the collection of plant material for an anatomic analysis was performed. With a hoe, a clump was withdrawn in each fractions, respecting the distance of 1 meter from the edge. Four root samples were removed from these portions, and the organs with the largest diameter of each cultivar were selected. Eight leaves of each cultivar per portion were also cultivated, always standardizing by the second leaf of the tiller. This material passed through the fixing process in FAA 50 (formaldehyde, glacial acetic acid and ethanol 50\% 5:5:90, v/v), it was maintained for 48 hours in a vacuum pump, and later was stored in ethanol at $70 \%$ (Johansen, 1940) in the Laboratory of Vegetal Biology of the University of the State of Mato Grosso, campus of Alta Floresta.

\subsection{Laboratory procedure}

Transverse sections of the middle third region of the roots and leaves were obtained freehand with a razor blade, discolored with the use of sodium hypochlorite at $2 \%$, stained with double staining, Astra blue and basic fuchsin (Roeser, 1962) and mounted in permanent and semi-permanent histological slides. 
For the analysis of the foliar epidermis, paradermic cuts in the adaxial and abaxial surface were made freehand with a razor blade. The dissociation method Kraus and Arduin (1997) modified was used, in which the leaf portions were placed in test tubes with hydrogen peroxide (30 volumes) and glacial acetic acid in the proportion of 1: 1 and they were kept in a greenhouse at $60^{\circ} \mathrm{C}$ for about 48 hours. After this period, the samples were washed in distilled water and ethanol $50 \%$. With a paint brush, the two epidermal surfaces were separated, and then they were stained with basic fuchsin (Roeser, 1962) and mounted in glycerinated gelatine.

For a histochemical analysis it was used the same material selected for anatomical study, as well as fresh samples. Tests using lugol were carried out on leaves and roots for the detection of starch (Johansen, 1940), phloroglucinol for the detection of lignin and suberin (Jensen, 1962) and toluidine blue for mucilage (O'Brien et al., 1965).

The slides were analyzed in a trinocular photonic microscope Leica ${ }^{\circledR}$ ICC50, coupled to a computer, and photomicrographs were recorded with the assistance of the software LAZ EZ 1.7.0.

In the images qualitative and quantitative anatomical characters were analyzed. They quantitatively assessed: (1) diameter of the root; (2) thickness of the root epidermis; (3) count of cores of protoxylem; (4) diameter of the vascular cylinder of the root; (5) proportion of the stomata and (6) subsidiaries cells; (7) size of the bulliform cells; (8) thickness of the foliar mesophyll; (9) thickness of the group of fibers of the abaxial and adaxial foliar rib; (10) diameter of the central vascular bundle of the foliar blade. Were qualitatively evaluated: (1) characteristics of epidermic cells; (2) cuticle; (3) thickness of the endoderm; (4) thickness of the exodermis; (5) hypodermis; (6) trichomes;

(7) mesophyll; (8) vascular and extravascular fibers and (9) vascular bundles.

From the photomicrographs, the tissues were measured and the stomatal count was done through the Anati Quanti program $2^{\circledR}$ UFV (Aguiar et al., 2007). Fot the calculation of the stomatal density, it was used the following formula: density $=$ number of stomata $\mathrm{mm}^{2}$ per leaf area. For the statistical analysis there were selected four images of transversal sections of root, four images of paradermic sections and four images of transversal sections of leaf per portion of collect, which totaled 12 repetitions per cultivar and 120 independent variables for each character analyzed quantitatively.

The data were subjected to analysis of variance by the F test and the averages were compared by the Tukey test at 5\% of probability (Ferreira, 2011). Posteriorly, images of each cultivar were selected and boards were set up to evidence anatomical patterns and differences among cultivars.

\section{Results and Discussion}

During the collection of the vegetal material, it was observed a large volume of roots with reduced diameter in the first $10 \mathrm{~cm}$ of soil, in the cultivars Tanzania and Mombaça. It was also noted the presence of a large amount of absorbent hairs in the roots of larger caliber of Estrela-roxa. Such characteristics may arise as a response to the anoxia in depth. These replacement roots usually emerge from the aereal base and/or in superficial layers of the soil (Vartapetian and Jackson, 1997).

From transversal sections, the roots of Llanero stood out with a larger diameter and a larger volume of epidermic cells compared to the other cultivars (Table 1).

It was registered unistratified epidermis, with cells with irregular size and shape, with walls slightly thickened in the ten cultivars analyzed (Figure 1a, 1b, 1c), which are common characteristics to the Poaceae (Alquini et al., 2003).

The cortex, bulky in the studied species, was composed of parenchyma of filling arranged in layers. Below the epidermis it was observed a layer of cells with thin walls, larger in Tanzania (Figure 1b). Exodermis, isodiametric cells with thickened walls with two well-defined layers was

Table 1. Morphometry of the middle third of the root of the ten cultivars of tropical forage. Epidermis (Epi), diameter of the root (Root diam), diameter of the vascular cylinder (VC diam), protoxylem (n), coefficient of variation (CV) and simple medium deviation (SMD).

\begin{tabular}{lcccc}
\hline \multicolumn{1}{c}{ Cultivar } & Epi $(\boldsymbol{\mu m})$ & Root diam $(\boldsymbol{\mu m})$ & VC Diam $(\boldsymbol{\mu m})$ & Protoxylem $(\mathbf{n})$ \\
\hline Tanzânia & $20.57 \mathrm{bc}$ & $1663.36 \mathrm{ab}$ & $912.38 \mathrm{ab}$ & $36.83 \mathrm{~b}$ \\
Mombaça & $18.47 \mathrm{bc}$ & $1327.02 \mathrm{c}$ & $765.24 \mathrm{bc}$ & $34.33 \mathrm{~b}$ \\
Llanero & $28.62 \mathrm{a}$ & $1926.41 \mathrm{a}$ & $670.54 \mathrm{~cd}$ & $28.16 \mathrm{~cd}$ \\
Piatã & $23.27 \mathrm{~b}$ & $1373.10 \mathrm{bc}$ & $632.70 \mathrm{~cd}$ & $31.91 \mathrm{bc}$ \\
Ruzizienses & $19.36 \mathrm{bc}$ & $879.22 \mathrm{e}$ & $416.81 \mathrm{e}$ & $22.00 \mathrm{e}$ \\
Mulato II & $22.12 \mathrm{bc}$ & $1237.46 \mathrm{~cd}$ & $553.04 \mathrm{de}$ & $28.91 \mathrm{~cd}$ \\
Massai & $18.83 \mathrm{bc}$ & $945.61 \mathrm{de}$ & $523.73 \mathrm{de}$ & $25.16 \mathrm{de}$ \\
Marandu & $19.89 \mathrm{bc}$ & $1661.73 \mathrm{ab}$ & $892.65 \mathrm{ab}$ & $35.50 \mathrm{~b}$ \\
Xaraés & $21.73 \mathrm{bc}$ & $1407.13 \mathrm{bc}$ & $679.22 \mathrm{~cd}$ & $34.75 \mathrm{~b}$ \\
Estrela-roxa & $17.76 \mathrm{c}$ & $1679.38 \mathrm{ab}$ & $975.09 \mathrm{a}$ & $42.25 \mathrm{a}$ \\
CV (\%) & 19.08 & 17.01 & 21.52 & 12.21 \\
SDM & 5.29 & 316.34 & 199.26 & 5.14 \\
\hline
\end{tabular}

Same letters in the column do not differ significantly ( $p>0.05)$, according to the Tukey's test. 

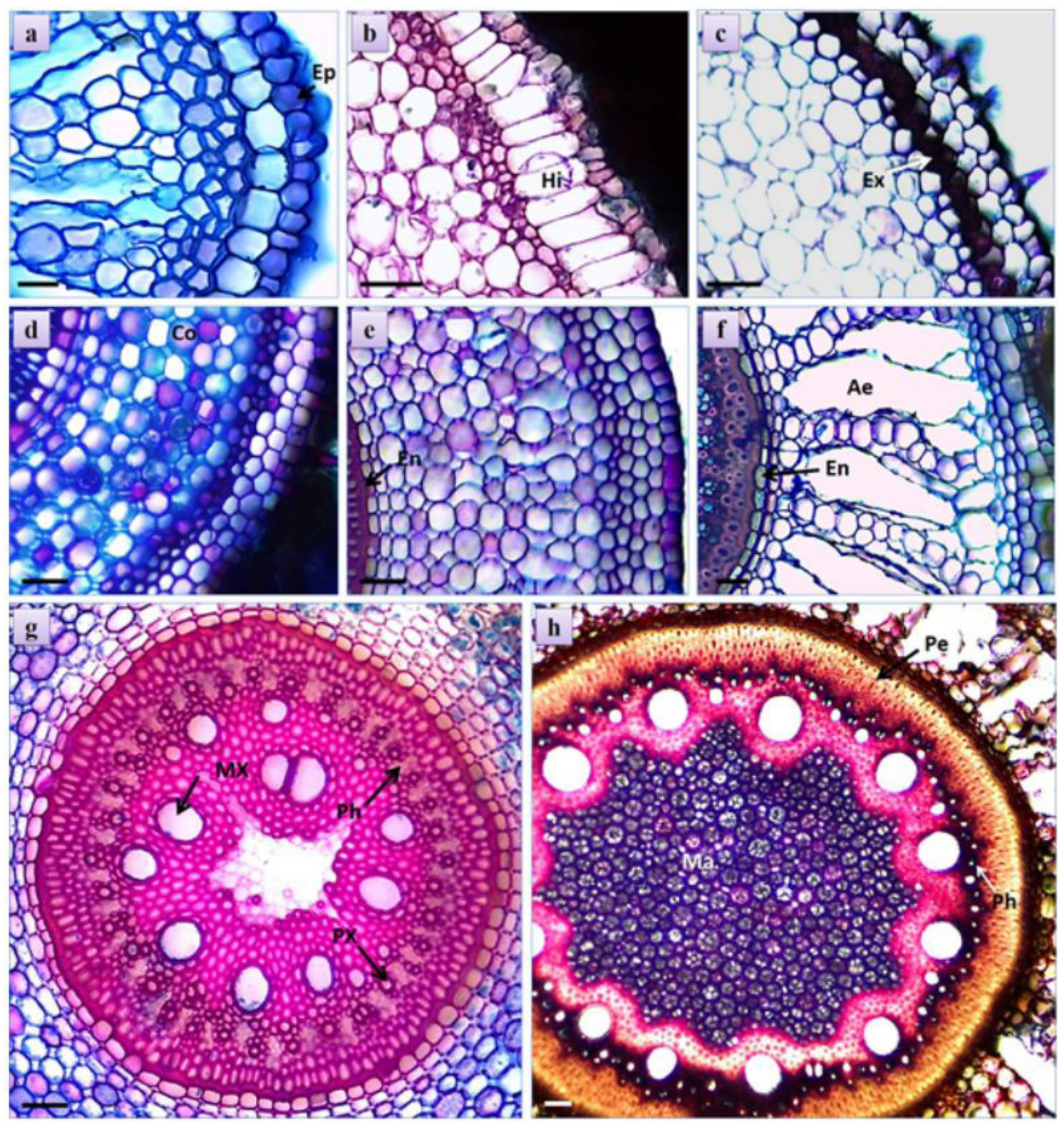

Figure 1. Details of the transversal sections of the middle third of the roots of tropical forages. Epidermis (Ep), hypodermis (Hi), exodermis (Ex), cortex (Co), endoderm (En), aerenchyma (Ae), metaxylem (MX), protoxylem (PX) phloem (Ph), pericycle (Pe) and parenchymatic marrow (Ma). (a) and (f) Llanero; (b) Tanzânia; (c) and (g) Xaraés; (d) Marandu; (e) Piatã; (h) Estrela-roxa. Bars $=50 \mu \mathrm{m}$.

seen in most cultivars. Llanero presented the largest cells in the exodermis (Figure 1a), while the cultivar Xaraés presented greater wall thickening (Figure 1c).

Baruch and Merida (1995), analyzing the Urochloa mutica (Forssk.) Stapf, classified the first layers of the cortex as hypodermis, further stating that probably the wall thickness of some layers occurs by accumulation of suberin and lignin. The abovementioned characteristics are similar to those observed in this study, and it was confirmed the presence of the substances through the test with phloroglucinol.
Tanzania, Mombaça, Marandu and Ruzizienses presented, in the central region of the cortex, isodiametric parenchymatic cells, with thin cell walls and symmetrically arranged layers (Figure 1d). The other cultivars showed the formation of aerenchyma (Figures 1e, 1f).

Aerenchyma were also observed in maize (Zea mays L.) under continuous flooding condition (Pereira et al., 2008), in 91 species tolerant to soil drenching (Justin and Armstrong, 1987), and in U. mutica, both in dry environment and swampy environment (Baruch and Mérida, 1995). The development of thicker roots, with a higher proportion of aerenchyma and a reduction of lateral 
roots may act together to a more efficient system for $\mathrm{O}_{2}$ transport (Cardoso et al., 2013).

Llanero presented the highest formations of aerenchyma (Figure 1f), which corroborates with the adaptive characteristic of the cultivar to soils with high level of humidity (Vilela, 2011).

The endoderm showed thickening of the periclinal and anticlines walls in the ten cultivars. Pereira et al. (2008) affirm that this suberised layer imposes resistance to the water flux to the vascular cylinder, its reduction can be related with the increase of aerenchyma and the environment in which the plant is inserted.

Mulato II, Llanero and Estrela-roxa presented a higher thickening of the walls of the endoderm (Figure 1g), with an increase of intercellular spaces in the cortex of Mulato II. The list of changes in the structures over time was not analyzed in this study.

The vascular cylinder (VC) was polyarc in the ten cultivars (Figure 1g), with significant differences in the diameter, which is larger in Tanzânia, Estrela-roxa and Xaraés (Table 1). Prominent pericycle formed by three or four layers of sclerified cells in Xaraés and Estrela-roxa (Figure 1h).

Pericycle with sclerified layers as well as thick endoderm, are common in plants more resistant to flooding. Plants well adapted to situations of radicular hypoxia have lower loss of dry mass of root in relation to poorly adapted plants (Cardoso et al., 2013). The maintenance of the sclerified layers of the pericycle is directly related to the root dry mass due to the low accumulation of fluid in the fibers.

Ruzizienses presented the lowest frequency of poles of protoxylem, while Estrela-roxa presented the greatest quantities (Table 1). A greater arrangement of protoxylem is related to the anatomy of the vascular cylinder (VC), the bundles of metaxylem and phloem, smaller, did not occupy as much space as other cultivars with VC of similar caliber (Figure 1h).

At the center of the VC it was registered a parenchymatic marrow with cells with thin walls in all cultivars. Estrela-roxa showed higher this tissue compared to other cultivars (Figure 1h), and a higher concentration of starch. This characteristic was proven by the test with lugol. The starch accumulation in parenchymatic cells can provide greater resistance to the plant and facilitate the process of regrowth, for providing energy quickly to the meristematic tissues (Machado et al., 2008).

In the leaves, the epidermic cell walls presented anticlinal walls with sinuous juxtaposition (Figure 2a, 2c, 2d, 2e), which can increase the contact surface among adjacent cells and hinder the tissue disruption (Carvalho and Pires, 2008). Cells very attached to each other, as occurred in the forages analyzed in this study make it difficult for the microorganisms to access the mesophyll, very easily digested region (Valente et al., 2011).

It was also recorded the presence of short cells, lined up, which received little color on treatment with basic fuchsin. They were described by Alquini et al. (2003) as siliceous cells (Figure 2b, 2c, 2d, 2e), very common in Poaceae (Ellis, 1979; Vieira et al., 2002). The amount of silicon in forage leaves is not decisive for the digestibility, due to the fact that plants with different silica contents also present different levels of other important components that greatly affect the digestibility, such as lignin contents, differentiated arrangements of cellulose fibrils (Silva et al., 2005).

There was a significant difference in the stomatal density among the cultivars (Table 2). The size of the stomata among the cultivars was visually discrepant. The cultivar Llanero presented polar measurement of the stomata about three times larger than the cultivar Estrela-roxa (Figure 2a, 2b).

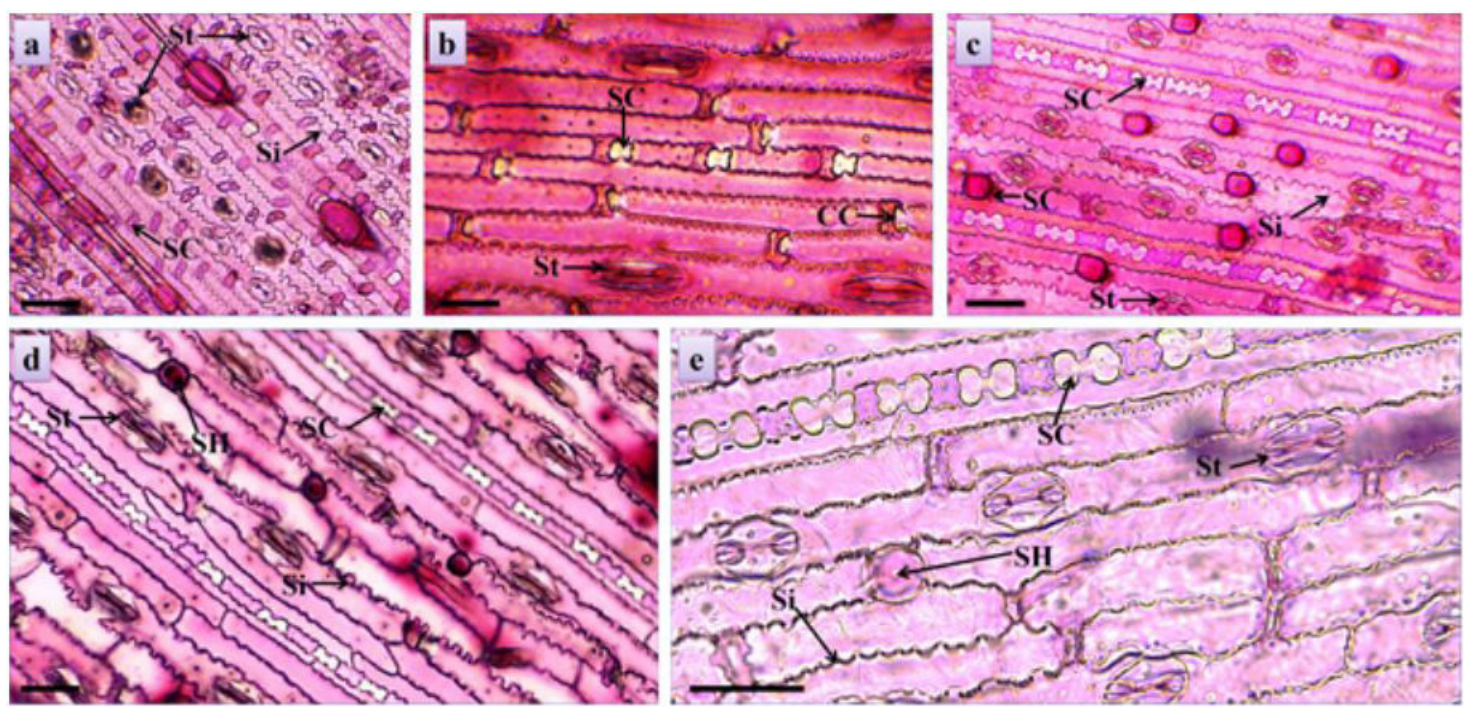

Figure 2. Paradermic sections of the leaves of tropical forages. Stomata (St), siliceous cells (SC), short cells (SH) and sinuosities (Si). (a) Estrela-roxa; (b) Llanero; (c) Massai; (d) Piatã; (e) Mombaça. Bars $=50 \mu \mathrm{m}$. 
Estrela-roxa presented greater stomatal density by adding the two faces of the leaf, which can provide higher digestibility, since microorganisms are dependent on the epidermis breakage by chewing, or on open stomata, initiating the digestion of the tissues, generally by the substomatal chamber (Brito and Deschamps, 2001).

It was registered a thin cuticle on both sides of the leaves of the cultivars (Figure 3a, 3b), uniestratified epidermis composed by notably larger abaxial cells in all analyzed cultivars (Figure 3c), most notably the volume of this layer in Piatã (Figure 3d). Bulliform cells were observed on both sides of the leaves, and in the adaxial face they are bulkier. This characteristic is common in representatives of Poaceae (Metcalfe and Chalk, 1960). The samples of Llanero stood out with bulkier groups of cells than the other cultivars (Table 2).

The analyzed cultivars presented these structures in higher quantities. This characteristic is common in tropical
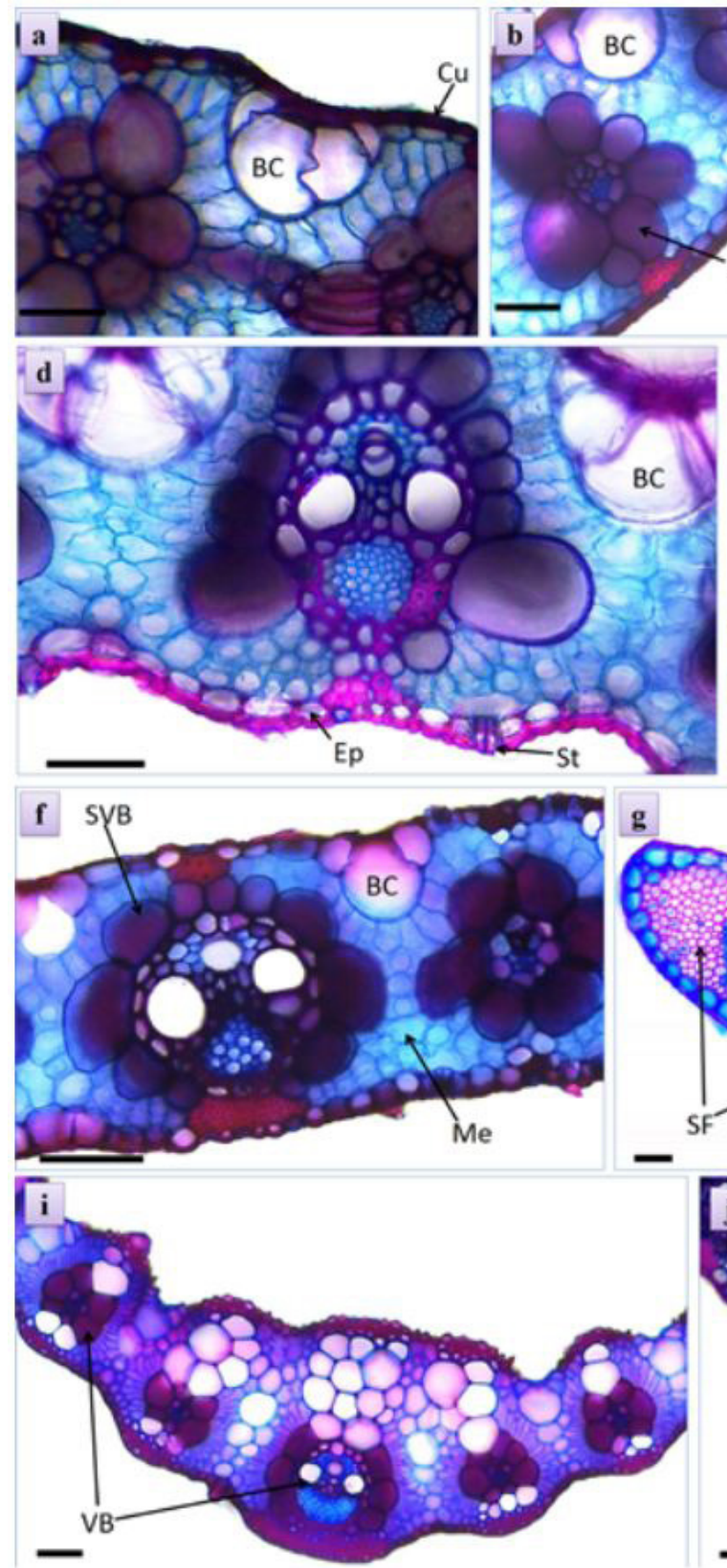
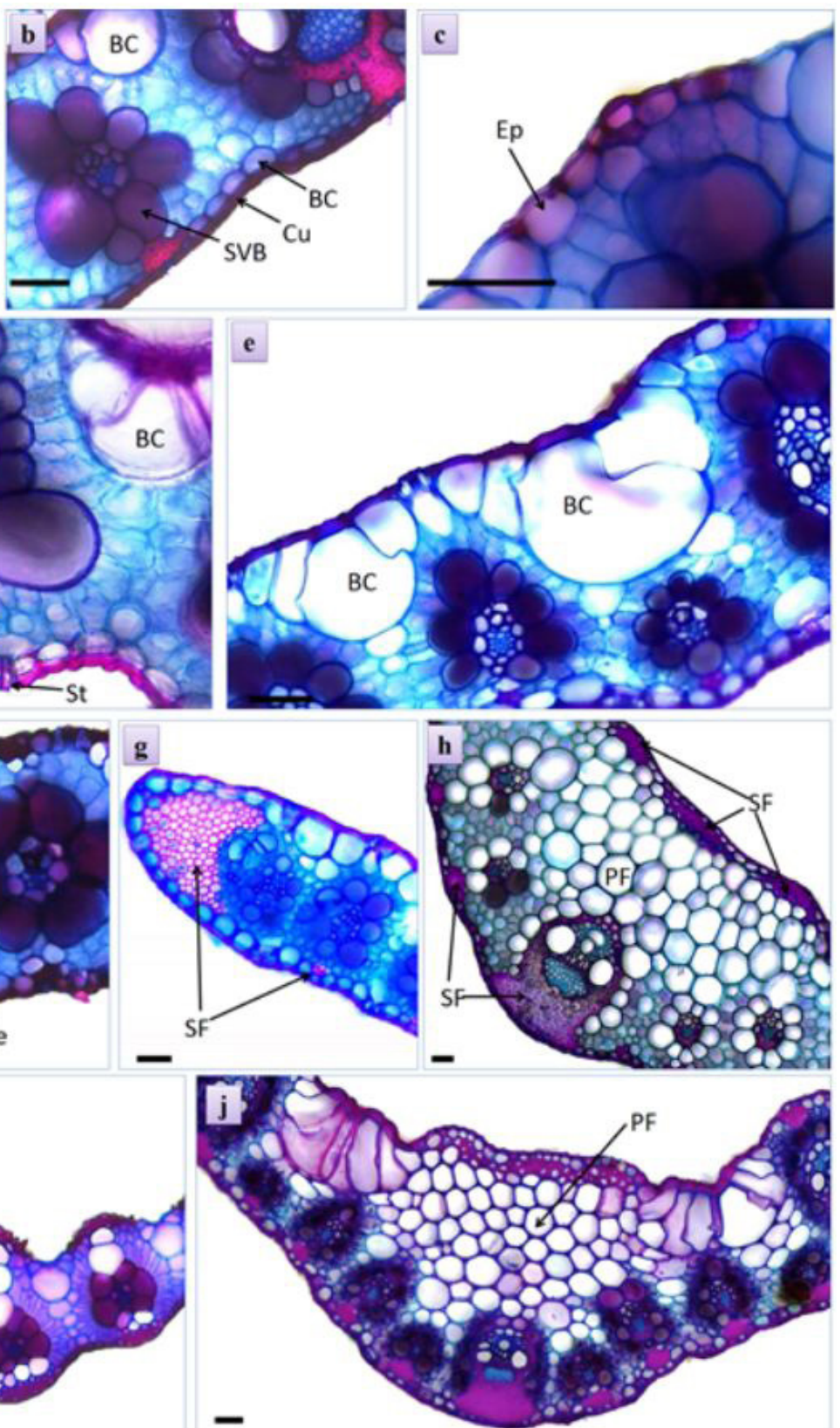

Figure 3. Transversal sections of the leaves of tropical forages. Cuticle $(\mathrm{Cu})$, epidermis (Ep), stomata (St), bulliform cell (BC), mesophyll (Me), sheath of the vascular bundle (SVB), sclerenchymatic fibers (SF), parenchyma of filling (PF), and vascular bundle (VB). (a) Marandu; (b) and (h) Xaraés; (c) Mombaça; (d) Piatã; (e), (g) and (j) Llanero; (f) Tanzânia; (i) Estrela-roxa. Bars $=50 \mu \mathrm{m}$. 
Table 2. Foliar morphometry of ten cultivars of tropical forage. Stomatal index (Stom index), stomatal density (Stom dens), midrib, bulliform cells (BC), sclerenchyma fibers (Fibers), mesophyll of the leaf blade (Mes), coefficient of variation (CV) and simple medium deviation (SMD).

\begin{tabular}{|c|c|c|c|c|c|c|c|}
\hline Cultivar & $\begin{array}{c}\begin{array}{c}\text { Stom dens } \\
\left(\mathbf{m m}^{2}\right)\end{array} \\
\end{array}$ & $\begin{array}{c}\text { Stom dens } \\
\left(\mathrm{mm}^{2}\right)\end{array}$ & $\mathrm{BC}(\mu \mathrm{m})$ & $\begin{array}{c}\text { Mibrid } \\
(\mu \mathrm{m})\end{array}$ & $\operatorname{Mes}(\mu \mathrm{m})$ & $\begin{array}{c}\text { Fibers } \\
(\mu \mathrm{m})\end{array}$ & $\begin{array}{c}\text { Fibers } \\
(\mu \mathrm{m})\end{array}$ \\
\hline & Abaxial & Adaxial & Adaxial & & & Abaxial & Adaxial \\
\hline Tanzânia & $155.14 \mathrm{ab}$ & $119.45 b$ & $79.11 b$ & $834.13 a$ & $206.38 b c$ & $78.28 \mathrm{bcd}$ & $23.86 \mathrm{~cd}$ \\
\hline Mombaça & $127.46 b c$ & $65.54 \mathrm{~cd}$ & $85.26 b$ & $532.86 \mathrm{cde}$ & $198.80 \mathrm{bcd}$ & $79.80 \mathrm{bcd}$ & 34.09abc \\
\hline Llanero & $33.44 \mathrm{e}$ & $23.37 \mathrm{e}$ & $121.07 \mathrm{a}$ & $636.70 \mathrm{abc}$ & $263.63 a$ & $62.00 \mathrm{~d}$ & $29.04 \mathrm{bcd}$ \\
\hline Piatã & $53.60 \mathrm{e}$ & $47.36 \mathrm{de}$ & $79.57 b$ & 542.93 bcde & $241.59 \mathrm{ab}$ & $90.89 b$ & $35.54 \mathrm{abc}$ \\
\hline Ruzizienses & $91.34 \mathrm{~cd}$ & $122.97 b$ & $70.90 b$ & $573.85 \mathrm{bcd}$ & $196.81 \mathrm{bcd}$ & $63.56 \mathrm{~cd}$ & $33.54 \mathrm{abc}$ \\
\hline Mulato II & $100.79 \mathrm{c}$ & $28.69 \mathrm{e}$ & $74.69 b$ & $381.58 \mathrm{de}$ & $210.64 b$ & $85.80 \mathrm{bc}$ & 29.76abcd \\
\hline Massai & $173.05 \mathrm{a}$ & $96.48 b c$ & $63.02 \mathrm{~b}$ & $567.17 \mathrm{bcd}$ & $152.81 \mathrm{~d}$ & $57.42 d$ & $17.57 \mathrm{~d}$ \\
\hline Marandu & $39.81 \mathrm{e}$ & $51.30 \mathrm{de}$ & $70.59 b$ & $616.57 \mathrm{bc}$ & $225.02 \mathrm{ab}$ & $115.06 \mathrm{a}$ & $37.53 \mathrm{ab}$ \\
\hline Xaraés & $62.02 \mathrm{de}$ & $46.92 \mathrm{de}$ & $73.27 b$ & 739.48ab & $247.93 \mathrm{ab}$ & $118.28 \mathrm{a}$ & $42.27 \mathrm{a}$ \\
\hline Estrela roxa & $158.39 \mathrm{ab}$ & $238.25 \mathrm{a}$ & $65.29 b$ & $361.00 \mathrm{e}$ & $156.34 \mathrm{~cd}$ & $60.33 d$ & $34.35 \mathrm{abc}$ \\
\hline CV (\%) & 12.99 & 13.85 & 24.81 & 26.34 & 18.57 & 21.57 & 31.08 \\
\hline SDM & 37.38 & 33.64 & 25.61 & 200.98 & 51.41 & 23.08 & 13.01 \\
\hline
\end{tabular}

Same letters in the column do not differ significantly $(p>0.05)$, according to the Tukey's test.

grasses and may increase as a result of the adaptation to the environment, for being responsible for the winding and unwinding of the leaf in warm periods, avoiding the loss of water (Paciullo et al., 2002).

The mesophyll was homogeneous, as described by Brito and Rodella (2002) to C4 grasses. It was verified the occurrence of a similar anatomical organization among the representatives of the three genera analyzed in this study. The thickness of the limbo of the Llanero (Table 2) is highlighted. Carvalho and Pires (2008) conclude that a higher proportion of these tissues in the leaf blade of a forage can mean a better utilization of nutrients by animals and thus a higher nutritional quality.

Cardoso et al. (2013) state that plants resistant to marshy soil can develop spaces among the tissues of the root, stem and leaves to better aeration. In this study it was not observed formation of aerenchyma in the leaves of the cultivars, maybe because they were not exposed to flooding or the waterlogging period to which these plants were exposed have been short.

Collateral vascular bundles of second order (Figure 3i) occurred periodically in the mesophyll of the leaf blade, interspersed with smaller frequency by first-order bundles (Figure $3 \mathrm{~g}$ ). The distance between the bundles differs among the cultivars, Massai presented the lowest average distances $(124,8 \mu \mathrm{m})$, and $U$. brizantha presented the highest averages $(220 \mu \mathrm{m})$ in the Marandu and Xaraés cultivars. More spaced bundles on the foliar limb may facilitate the rupture of limbo at the moment of the grazing, especially for bovine animals (Brito and Deschamps, 2001).

The cultivars Xaraés and Marandu presented higher proportion of sclerenchyma fibers on both sides of the leaf, with greater emphasis on the abaxial face (Figure $3 \mathrm{~h}$ ), while the Massai cultivar presented the lowest results for the quantity of fibers (Table 2), increasing its digestibility, since the condition of higher amount of subepidermic fibers may negatively interfere on the digestibility of the forage by the cattle, due to the lignin in the walls of sclerenchyma cells (Paciullo et al., 2002).

The cultivars of the Panicum gender analyzed here presented cells of the sheath of the vascular bundle (SVB) with thinner cell walls than the cultivars of the genus Urochloa, which may contribute to a higher productivity/yield of ruminant that eat these forages (Vilela, 2011).

The cells of SVB are rich in photosynthetic enzymes and non-structural carbohydrates, which can positively interfere on the productivity and chemical composition of the leaf blades (Gomes et al., 2011). However, Carvalho and Pires (2008) highlighted that their digestion is slow or incomplete due to their thickened cell wall, which hinders the access of the ruminal microorganisms to the nutrients inside these cells.

\section{Conclusions}

Massai, Piatã, Xaraés, Llanero, Mulato II, Estrela-roxa and Llanero presented the highest formations of aerenchyma, which may be related to the adaptation to the environment subject to flooding. The higher stomatal density of Estrela-roxa, adding the two sides of the leaf, the size of cells bulliform and chlorophilian parenchyma of Llanero, plus the low proportion of the fibers from both, provide highlights on the digestibility in relation to the other cultivars, as well as Massai that presented the smallest results for amount of fibers.

\section{References}

AGUIAR, T.V., SANT'ANNA-SANTOS, B.F., AZEVEDO, A.A. and FERREIRA, R.S., 2007. Anati Quanti: software de análises quantitativas para estudos em anatomia vegetal. Planta Daninha, vol. 25, no. 4, pp. 649-659. http://dx.doi.org/10.1590/ S0100-83582007000400001. 
ALQUINI, Y., BONA, C., BOEGER, M.R.T., COSTA, C.G. and BARROS, C.F., 2003. Epiderme. In: B. APPEZZATO-DAGLÓRIA and S.M. CARMELLO-GUERREIRO, eds. Anatomia vegetal. Viçosa: Editora UFV, pp. 87-108.

BARUCH, Z. and MÉRIDA, T., 1995. Effects of drought and flooding on root anatomy in four tropical forage grasses. International Journal of Plant Sciences, vol. 156, no. 4, pp. 514-521. http://dx.doi.org/10.1086/297274.

BRITO, C.J.F.A. and DESCHAMPS, F.C., 2001. Caracterização anatômica em diferentes frações de cultivares de capim-elefante (Pennisetum purpureum Schumach.). Revista Brasileira de Zootecnia, vol. 30, no. 5, pp. 1409-1417. http://dx.doi.org/10.1590/ S1516-35982001000600004.

BRITO, C.J.F.A. and RODELLA, R.A., 2002. Caracterização morfo-anatômica da folha e do caule de Urochloa brizantha (Hochst. ex A. Rich.) Stapf e B. humidicola (Rendle) Schweick. (Poaceae). Revista Brasileira de Botanica. Brazilian Journal of Botany, vol. 25, no. 2, pp. 221-228. http://dx.doi.org/10.1590/ S0100-84042002000200010.

CARDOSO, J.A., RINCÓN, J., JIMÉNEZ, J.C., NOGUERA, D. and RAO, I.M., 2013. Morpho-anatomical adaptations to waterlogging by germplasm accessions in a tropical forage grass. AoB Plants, vol. 5, no. 0, pp. 1-14. http://dx.doi.org/10.1093/aobpla/plt047.

CARVALHO, G.G.P. and PIRES, A.J.V., 2008. Organização dos tecidos de plantas forrageiras e suas implicações para os ruminantes. Archivos de Zootecnia, vol. 57, pp. 13-28.

ELLIS, R.P., 1979. A procedure for standardizing comparative leaf anatomy in the Poaceae. The epidermis as seen in surface view. Bothalia, vol. 12, no. 4, pp. 641-671. http://dx.doi.org/10.4102/ abc.v12i4.1441.

FERREIRA, D.F., 2011. Sisvar: a computer statistical analysis system. Ciência e Agrotecnologia. Ciência e Agrotecnologia, vol. 35 , no. 6 , pp. 1039-1042.

GERDES, L., WERNER, J.C., COLOZZA, M.T., POSSENTI, R.A. and SCHAMMASS, E.A., 2000. Avaliação de características de valor nutritivo das gramíneas forrageiras Marandu, Setária e Tanzânia nas estações do ano. Revista Brasileira de Zootecnia, vol. 29, no. 4, pp. 955-963. http://dx.doi.org/10.1590/S151635982000000400003 .

GOMES, R.A., LEMPP, B., JANK, L., CARPEJANI, G.C. and MORAIS, M.G., 2011. Características anatômicas e morfofisiológicas de lâminas foliares de genótipos de Panicum maximum. Pesquisa Agropecuaria Brasileira, vol. 46, no. 2, pp. 205-211. http://dx.doi. org/10.1590/S0100-204X2011000200013.

JENSEN, W.A., 1962. Botanical histochemistry, principles and practice. San Francisco: W.H. Freeman. 408 p.

JOHANSEN, D.A., 1940. Plant microtechnique. New York: McGraw-Hill.

JUSTIN, S.H.F. and ARMSTRONG, W., 1987. The anatomical characteristics of roots and plant response to soil flooding. The New Phytologist, vol. 106, no. 3, pp. 465-495. http://dx.doi. org/10.1111/j.1469-8137.1987.tb00153.x.

KRAUS, J.E. and ARDUIN, M., 1997. Manual básico de métodos em morfologia vegetal. Rio de Janeiro: EDUR. 198 p.
MACHADO, A.F.L., MEIRA, R.M.S., FERREIRA, L.R., FERREIRA, F.A., TUFFI SANTOS, L.D., FIALHO, C.M.T. and MACHADO, M.S., 2008. Caracterização anatômica de folha, colmo e rizoma de Digitaria insularis. Planta Daninha, vol. 26, no. 1, pp. 1-8. http://dx.doi.org/10.1590/S0100-83582008000100001.

METCALFE, C.R. and CHALK, L., 1960. Anatomy of monocotyledons: Gramineae. Oxford: Clarendon Press. 731 p. vol. 1.

O'BRIEN, T.P., FEDER, N. and MCCULLY, M.E., 1965. Polychromatic staining of plant cell walls by toluidine blue O. Protoplasma, vol. 59, no. 2, pp. 368-373. http://dx.doi.org/10.1007/ BF01248568.

PACIULLO, D.S.C., GOMIDE, J.A., SILVA, E.A.M., QUEIROZ, D.S. and GOMIDE, C.A.M., 2002. Características Anatômicas da Lâmina Foliar e do Colmo de Gramíneas Forrageiras Tropicais, em Função do Nível de Inserção no Perfilho, da Idade e da Estação de Crescimento. Revista Brasileira de Zootecnia, vol. 31, no. 2, pp. 890-899. http://dx.doi.org/10.1590/S1516-35982002000400012.

PEREIRA, F.J., CASTRO, E.M., SOUZA, T.C. and MAGALHÃES, P.C., 2008. Evolução da anatomia radicular do milho 'Saracura' em ciclos de seleção sucessivos. Pesquisa Agropecuaria Brasileira, vol. 43, no. 12, pp. 1649-1656. http://dx.doi.org/10.1590/S0100204X2008001200002.

QUEIROZ, D.S., GOMIDE, J.A. and MARIA, J., 2000. Avaliação da folha e do colmo de topo e base de perfilhos de três gramíneas forrageiras. Revista Brasileira de Zootecnia, vol. 29, no. 1, pp. 61-68. http://dx.doi.org/10.1590/S1516-35982000000100009.

ROESER, K.R., 1962. Die nadel der Schwarzkiefer-masenprodukt und Keinstwert der Natur. Microkosmos, vol. 61, pp. 33-36.

SECRETARIA DE ESTADO DE PLANEJAMENTO E COORDENAÇÃO GERAL - SEPLAN. Unidades Climáticas do Estado de Mato Grosso, 2006. Zoneamento Sócio Econômico Ecológico: Atlas Climatológico de Mato Grosso. Cuiabá: Laboratório de Climatologia, UFMT. CD-ROM.

SILVA, L.P.D., SILVA, L.S.D. and BOHNEN, H., 2005. Componentes da parede celular e digestibilidade in vitro de palha de arroz (Oryza sativa) com diferentes teores de silício. Ciência Rural, vol. 35, no. 5, pp. 1205-1208. http://dx.doi.org/10.1590/ S0103-84782005000500036.

VALENTE, T.N.P., LIMA, E.S., HENRIQUES, L.T., MACHADO NETO, O.R., GOMES, D.I., SAMPAIO, C.B. and COSTA, V.A.C., 2011. Anatomia de plantas forrageiras e a disponibilidade de nutrientes para ruminantes. Veterina-ria e Zootecnia, vol. 18, no. 3, pp. 347-358.

VARTAPETIAN, B.B. and JACKSON, M.B., 1997. Plant adaptations to anaerobic stress. Annals of Botany, vol. 79, no. 1, suppl. 1, pp. 3-20. http://dx.doi.org/10.1093/oxfordjournals.aob.a010303.

VIEIRA, R.C., GOMES, D.M.S., SARAHYBA, L.S. and ARRUDA, R.C.O., 2002. Leaf anatomy of three herbaceous bamboo species. Brazilian Journal of Biology $=$ Revista Brasileira de Biologia, vol. 62, no. 4B, pp. 907-922. PMid:12659043. http://dx.doi. org/10.1590/S1519-69842002000500021.

VILELA, F.,2011. Pastagem: seleção de plantas forrageiras, implantação e adubação. Viçosa: Aprender Fácil. 284 p. 